\title{
KHDRBS3 wt Allele
}

National Cancer Institute

\section{Source}

National Cancer Institute. KHDRBS3 wt Allele. NCI Thesaurus. Code C162401.

Human KHDRBS3 wild-type allele is located in the vicinity of 8q24.23 and is approximately $199 \mathrm{~kb}$ in length. This allele, which encodes KH domain-containing, RNA-binding, signal transduction-associated protein 3, plays a role in the regulation of alternative splicing. A fusion involving this gene and the ANGPT 1 gene may be associated with acute myeloid leukemia. 